\title{
Article \\ Spectrum of Kidney Injury Following COVID-19 Disease: Renal Biopsy Findings in a Single Italian Pathology Service
}

\author{
Alessandro Gambella ${ }^{1}$ (D), Antonella Barreca ${ }^{2}$, Luigi Biancone ${ }^{3}$, Dario Roccatello ${ }^{4}$ De $_{\text {, Licia Peruzzi }}{ }^{5}$ (D), \\ Luca Besso ${ }^{6}$, Carolina Licata $^{7}$, Angelo Attanasio ${ }^{1}$, Mauro Papotti ${ }^{8}$ and Paola Cassoni ${ }^{1, *(D)}$
}

check for

updates

Citation: Gambella, A.; Barreca, A.; Biancone, L.; Roccatello, D.; Peruzzi, L.; Besso, L.; Licata, C.; Attanasio, A.; Papotti, M.; Cassoni, P. Spectrum of Kidney Injury Following COVID-19 Disease: Renal Biopsy Findings in a Single Italian Pathology Service. Biomolecules 2022, 12, 298. https:// doi.org/10.3390/biom12020298

Academic Editor: Gianandrea Pasquinelli

Received: 12 January 2022

Accepted: 10 February 2022

Published: 12 February 2022

Publisher's Note: MDPI stays neutral with regard to jurisdictional claims in published maps and institutional affiliations.

Copyright: (C) 2022 by the authors. Licensee MDPI, Basel, Switzerland. This article is an open access article distributed under the terms and conditions of the Creative Commons Attribution (CC BY) license (https:// creativecommons.org/licenses/by/ $4.0 /)$.
1 Pathology Unit, Department of Medical Sciences, University of Turin, Via Santena 7, 10126 Turin, Italy; alessandro.gambella@unito.it (A.G.); angelo.attanasio@unito.it (A.A.)

2 Pathology Unit, "Città della Salute e della Scienza di Torino" University Hospital, Via Santena 7, 10126 Turin, Italy; abarreca@cittadellasalute.to.it

3 Division of Nephrology Dialysis and Transplantation, AOU Città della Salute e della Scienza di Torino, Department of Medical Sciences, University of Turin, 10126 Turin, Italy; luigi.biancone@unito.it

4 CMID, Coordinating Center of the Network for Rare Diseases of Piedmont and Aosta Valley, Nephrology and Dialysis Unit (ERK-Net Member), San Giovanni Bosco Hub Hospital, University of Turin, 10144 Turin, Italy; dario.roccatello@unito.it

5 Pediatric Nephrology Unit, Regina Margherita Department, AOU Città della Salute e della Scienza di Torino, 10126 Turin, Italy; licia.peruzzi@unito.it

6 Division of Nephrology and Dialysis, AO S. Croce e Carle di Cuneo, 12100 Cuneo, Italy; besso.1@ospedale.cuneo.it

7 Division of Nephrology and Dialysis, ASL TO4, 10073 Ciriè, Italy; carola.licata@libero.it

8 Pathology Unit, Department of Oncology, University of Turin, Via Santena 7, 10126 Turin, Italy; mauro.papotti@unito.it

* Correspondence: paola.cassoni@unito.it

\begin{abstract}
The onset of coronavirus disease (COVID-19) as a pandemic infection, has led to increasing insights on its pathophysiology and clinical features being revealed, such as a noticeable kidney involvement. In this study, we describe the histopathological, immunofluorescence, and ultrastructural features of biopsy-proven kidney injury observed in a series of SARS-CoV-2 positive cases in our institution from April 2020 to November 2021. We retrieved and retrospectively reviewed nine cases (two pediatric and seven adults) that experienced nephrotic syndrome (six cases), acute kidney injury (two cases), and a clinically silent microhematuria and leukocyturia. Kidney biopsies were investigated by means of light microscopy, direct immunofluorescence, and electron microscopy. The primary diagnoses were minimal change disease (four cases), acute tubular necrosis (two cases), collapsing glomerulopathy (two cases), and C3 glomerulopathy (one case). None of the cases showed viral or viral-like particles on ultrastructural analysis. Novel and specific histologic features on kidney biopsy related to SARS-CoV-2 infection have been gradually disclosed and reported, harboring relevant clinical and therapeutic implications. Recognizing and properly diagnosing renal involvement in patients experiencing COVID-19 could be challenging (due to the lack of direct proof of viral infection, e.g., viral particles) and requires a proper integration of clinical and pathological data.
\end{abstract}

Keywords: COVID-19; SARS-CoV-2; kidney biopsy; electron microscopy; minimal change disease acute tubular necrosis

\section{Introduction}

Coronavirus disease (COVID-19) is an infectious disease officially recognized as a pandemic by the WHO on 11 March 2020. It is caused by severe acute respiratory syndrome coronavirus type 2 (SARS-CoV-2), an enveloped, positive-strand RNA virus of the Coronaviridae family [1]. Historically, coronaviruses harbored the potential to infect humans and the peculiar ability to cause severe respiratory illness, as demonstrated by Severe Acute Respiratory Syndrome (SARS-CoV) and Middle East Respiratory Syndrome (MERS) in $2002 / 2003$ and 2012/2013, respectively [2,3]. 
Since its first outbreak in Wuhan (China) in 2019, SARS-CoV-2 demonstrated a distinct airway tropism potentially leading to severe clinical manifestations (e.g., pneumonia, acute respiratory distress syndrome) and imaging confirmed lung involvement (e.g., diffuse bilateral areas of consolidation and ground-glass opacities) [4,5]. However, as the disease spread globally, reaching more than 100 million cases and 2 million deaths within a year, clinical scenarios of a broader systemic involvement affecting distinct organs emerged more clearly together with a broader spectrum of symptom severity [6-13]. To date, additional symptoms are described due to gastrointestinal (e.g., nausea, vomiting, diarrhea, and abdominal pain), hepatic (e.g., acute liver injury and cholestasis), neurological (e.g., anosmia, ageusia, encephalitis, myelitis, encephalomyelitis, stroke, and neuralgia), cardiovascular (e.g., arrhythmias, acute myocardial injury, and chronic dilated cardiomyopathy), and genitourinary (e.g., acute kidney injury, proteinuria, and hematuria) involvement [14-25]. Among these, kidneys have been significantly affected due to several SARS-CoV-2 pathophysiological elements.

SARS-CoV-2 accesses and infects human cells through its Spike protein (i.e., one of the four virion proteins) binding and interacting with the angiotensin-converting enzyme-2 (ACE-2) receptor, a molecule that is widely expressed in the respiratory, hepatic, urinary, and digestive systems. Indeed, even if the airway represents the main gateway for virushost infection, every cell expressing the ACE-2 cell-surface receptor could be directly infected by the virus [26]. Once attached to ACE-2, the Spike protein is cleaved and the viral RNA is released within the host cell, eventually producing up to 1.000 virions per day by the infected cell [27-30]. In the kidney, the ACE-2 receptor is particularly expressed by convoluted proximal tubule epithelial cells, glomerular podocytes, and renal capillaries endothelium, where it contributes to regulating blood pressure, natriuresis, and blood volume [31,32]. In this regard, renal involvement during COVID-19 could either result from (1) a direct renal cell infection through ACE-2 receptor, (2) an indirect cytokine storminduced injury, (3) the local tissue deposition of immune complexes of viral antigens, or (4) an endothelial damage-related injury due to microvascular dysfunction and lymphocytic endothelialitis $[24,33,34]$. Altogether, these conditions have made the kidney an ideal target for COVID-19-related organ injury.

Acute and chronic SARS-CoV-2 related kidney injuries are now a well-established potential development of the infection with relevant consequences both in the native and transplant setting [6,24,33-52]. Indeed, more than $40 \%$ of COVID-19 hospitalized patients have presented laboratory evidence of kidney injury (i.e., albuminuria, proteinuria, hematuria, increased creatininemia and BUN, and reduced eGFR), eventually leading to acute kidney injury (AKI) and requiring kidney replacement therapy $[46,53,54]$.

In this setting, correctly identifying COVID-19-related morphologic features of kidney involvement will prove crucial for patient clinical management. Kidney biopsy performed during COVID-19 allows to identify a subset of morphological findings related to SARSCoV-2 infection, such as collapsing glomerulopathy (CG) and other forms of focal segmental glomerulosclerosis, acute tubular necrosis (ATN), IgA nephropathy, thrombotic microangiopathy, crescentic glomerulonephritis, minimal change disease (MCD), membranous nephropathy, and anti-glomerular basement membrane disease (Table 1) [55-94].

Electron microscopy (EM) has also played a significant role in the COVID-19 narrative even before the pandemic, considering that the name "coronavirus" itself derived from the club-shaped spines surrounding the virus and recalling the shape of a crown (i.e., Corona) on EM analysis [34,95-97].

Based on a monocentric case series, this study aims to analyze and report the main histopathological and ultrastructural findings of SARS-CoV-2 related kidney injury to foster and improve the diagnostic awareness and the timely clinical management of these conditions. 
Table 1. Pathology features of kidney involvement in COVID-19.

\begin{tabular}{|c|c|}
\hline Pathology Features & Reference \\
\hline $\begin{array}{l}\text { Collapsing glomerulopathy } \\
\text { (now defined as COVID-19-associated nephropathy (COVAN)) }\end{array}$ & {$[56-58,61,62,64,66,69-82]$} \\
\hline Acute tubular necrosis & {$[58,64,66,69,71,72,76,80,82-84]$} \\
\hline IgA nephropathy & {$[66,69,81,85-87]$} \\
\hline Thrombotic microangiopathy & {$[58,64,66,67,69]$} \\
\hline Crescentic glomerulonephritis & {$[58,66,69,88,89]$} \\
\hline Non collapsing FSGS & {$[64,66,69,84]$} \\
\hline Minimal change disease & {$[64,69,71,80]$} \\
\hline Membranous nephropathy & {$[66,69,71,81]$} \\
\hline Anti-glomerular basement membrane disease & {$[69,71,90,91]$} \\
\hline Diabetic nephropathy & {$[64,69,81]$} \\
\hline Myoglobin cast nephropathy & {$[58,69]$} \\
\hline Post-infectious glomerulonephritis & {$[64,69]$} \\
\hline Antibody-mediated rejection & {$[64,69]$} \\
\hline Light chain cast nephropathy & {$[66,69]$} \\
\hline Calcineurin inhibitor nephrotoxicity & [66] \\
\hline Amyloidosis & {$[66,69]$} \\
\hline Cortical infarction & {$[69,71]$} \\
\hline Lupus nephritis & {$[69,71]$} \\
\hline T-cell mediated rejection & {$[69,71]$} \\
\hline Acute interstitial nephritis & {$[69,91]$} \\
\hline Oxalate nephropathy & [92] \\
\hline Granulomatous tubulointerstitial nephritis & [93] \\
\hline Membranoproliferative glomerulonephritis & [94] \\
\hline
\end{tabular}

\section{Materials and Methods}

We analyzed the medical reports and pathology files of the Città della Salute e della Scienza Hospital in Turin, from April 2020 to November 2021, to retrospectively identify cases that presented biopsy-proven kidney injury related to COVID-19. To guarantee a strict correlation with SARS-CoV-2 infection, we selected cases that (1) developed clinical signs and symptoms of kidney injury during COVID-19, (2) resulted in a positive to SARS-CoV-2 test on admission and (3) were positive at the time of the biopsy. We retrieved 9 cases that satisfied these criteria and then collected the corresponding clinical and pathology data to create a database anonymized by a pathology staff member not involved in the study before starting any analysis.

Original slides and ultrastructural images were retrieved and reviewed by expert renal pathologists. At the time of diagnosis, histopathological, immunohistochemical (IHC), and immunofluorescence (IF) analyses were performed according to our laboratory clinical protocols, as previously described [98]. IHC and IF antibodies are detailed in Supplementary Methods. EM was performed by adopting standard protocols, thus requiring glutaraldehyde-based fixation and epoxy resin embedding. Then, single ultrathin sections 50-100 nm thick were obtained and analyzed using the Philips CM10 transmission electron microscope (Philips Electronics, Eindhoven, The Netherlands). 


\section{Results}

\subsection{Overall Population}

Our series was composed of nine cases developing kidney injury during SARS-CoV-2 infection. The most represented kidney-related clinical manifestation was nephrotic syndrome (five cases) followed by AKI (two cases). One case presented combined AKI and nephrotic syndrome, and one case was a mild clinical silent renal involvement characterized by microhematuria and leukocyturia. Males and females were almost equally represented (five and four cases, respectively) and the median age was 64 (interval: 15-80). Most cases were Caucasian (seven), whereas two cases were Afro-American.

Regarding the histopathological analysis, most cases presented features of minimal change disease (MCD) (four), followed by acute tubular necrosis (ATN) (two) and collapsing glomerulopathy (CG) (two). One case only presented C3 glomerulonephritis (C3G). Cases 2 and 4 presented overlapping features (ATN/microangiopathic glomerular injury and ATN/CG, respectively) and they were classified according to the prevalent pattern observed (ATN and CG). Light microscopy (LM) and immunofluorescence (IF) were always performed, whereas electron microscopy (EM) was not performed in one case due to tissue exhaustion. Case 1 required immunohistochemical stains (IHC) for C4d and SV40 to exclude post-transplant complications, whereas C4d was also performed in Case 9 for diagnostic differential purposes. Additionally, Caveolin-1 (Cav1) was tested for in Case 2 as a marker of thrombotic microangiopathy (TMA).

Clinical and pathology data are summarized in Table 2.

Table 2. Clinical and pathology data of our series.

\begin{tabular}{|c|c|c|c|c|c|c|c|}
\hline Cases & Sex/Age & $\begin{array}{c}\text { Risk Factor/Clinical } \\
\text { History }\end{array}$ & $\begin{array}{c}\text { Clinical } \\
\text { Background } \\
\text { on Admission * }\end{array}$ & $\begin{array}{c}\text { Kidney } \\
\text { Impairment }\end{array}$ & Laboratory Data $\S$ & $\begin{array}{l}\text { Analysis } \\
\text { Performed }\end{array}$ & $\begin{array}{l}\text { Pathology } \\
\text { Features }\end{array}$ \\
\hline Case 1 & $\mathrm{M} / 73$ & $\begin{array}{c}\text { Kidney transplant; } \\
\text { hypertension; metabolic } \\
\text { syndrome }\end{array}$ & $\begin{array}{l}\text { Elevated } \\
\text { fever }\end{array}$ & AKI & $\begin{array}{l}\text { Creatininemia: } 4.0 \mathrm{mg} / \mathrm{dL} \\
\text { Proteinuria: } 0.64-1 \mathrm{gr} / \mathrm{die}\end{array}$ & $\begin{array}{l}\text { LM; IHC; IF; } \\
\text { EM }\end{array}$ & ATN \\
\hline Case 2 & $\mathrm{~F} / 77$ & $\begin{array}{l}\text { Hypertension; obesity; } \\
\text { rheumatoid arthritis }\end{array}$ & Pneumonia & AKI & $\begin{array}{c}\text { Creatininemia: } 3.2 \mathrm{mg} / \mathrm{dL} \\
\text { Proteinuria: } 0.17 \mathrm{gr} / \mathrm{die}\end{array}$ & LM; IF; EM & ATN and TMA \\
\hline Case 3 & $\mathrm{~F} / 61$ & $\begin{array}{l}\text { Hypertension; obesity; } \\
\text { type } 2 \text { diabetes }\end{array}$ & $\begin{array}{l}\text { Acute respiratory } \\
\text { distress syndrome }\end{array}$ & $\begin{array}{l}\text { Nephrotic } \\
\text { syndrome }\end{array}$ & $\begin{array}{l}\text { Proteinuria: } 14 \mathrm{gr} / \mathrm{die} \\
\text { Albuminemia: } 2.2 \mathrm{~g} / \mathrm{dL}\end{array}$ & LM; IF; EM & CG \\
\hline Case 4 & $\mathrm{M} / 45$ & $\begin{array}{c}\text { Hypertension; type } 2 \\
\text { diabetes }\end{array}$ & Fatigue; dyspnea & $\begin{array}{l}\text { Nephrotic } \\
\text { syndrome }\end{array}$ & Proteinuria: $30 \mathrm{gr} / \mathrm{die}$ & LM; IF & ATN and CG \\
\hline Case 5 & $\mathrm{M} / 15$ & None & $\begin{array}{c}\text { Fever; fatigue; } \\
\text { peripheral edema }\end{array}$ & $\begin{array}{l}\text { Nephrotic } \\
\text { syndrome }\end{array}$ & $\begin{array}{c}\text { Proteinuria: } \\
1.83 \mathrm{gr} / \mathrm{die} / 1.73 \mathrm{~m}^{2} \\
\text { Albuminemia: } 3.9 \mathrm{~g} / \mathrm{dL}\end{array}$ & LM; IF; EM & $\mathrm{MCD}$ \\
\hline Case 6 & $\mathrm{M} / 71$ & Hypertension; obesity; & $\begin{array}{c}\text { Pneumonia; peripheral } \\
\text { edema }\end{array}$ & $\begin{array}{l}\text { Nephrotic } \\
\text { syndrome }\end{array}$ & $\begin{array}{l}\text { Proteinuria: } 15.3 \mathrm{gr} / \mathrm{die} \\
\text { Albuminemia: } 2.3 \mathrm{~g} / \mathrm{dL}\end{array}$ & LM; IF; EM & MCD and ATN \\
\hline Case 7 & $\mathrm{~F} / 80$ & Hypertension & Peripheral edema & $\begin{array}{l}\text { Nephrotic } \\
\text { syndrome }\end{array}$ & $\begin{array}{l}\text { Proteinuria: } 3.8 \mathrm{gr} / \mathrm{die} \\
\text { Albuminemia: } 2.5 \mathrm{~g} / \mathrm{dL}\end{array}$ & LM; IF; EM & MCD and ATN \\
\hline Case 8 & $\mathrm{M} / 64$ & Hypertension & Peripheral edema & $\begin{array}{l}\text { AKI and } \\
\text { Nephrotic } \\
\text { syndrome }\end{array}$ & $\begin{array}{c}\text { Creatininemia: } 2.8 \mathrm{mg} / \mathrm{dL} \\
\text { Proteinuria: } 22 \mathrm{gr} / \mathrm{die} \\
\text { Albuminemia: } 2.7 \mathrm{~g} / \mathrm{dL}\end{array}$ & LM; IF; EM & MCD \\
\hline Case 9 & $\mathrm{~F} / 15$ & None & Fever & $\begin{array}{l}\text { Microhematuria; } \\
\text { leukocyturia }\end{array}$ & $\begin{array}{c}\text { Creatininemia: } 1.1 \mathrm{mg} / \mathrm{dL} \\
\text { eGFR } 60 \mathrm{~mL} / \mathrm{min} / 1.73 \mathrm{~m}^{2} \\
\text { Proteinuria: } \\
1.9 \text { gr } / \text { die } / 1.73 \mathrm{~m}^{2} \\
\text { Albuminemia: } 3.7 \mathrm{~g} / \mathrm{dL} \\
\text { ANCA negative }\end{array}$ & $\begin{array}{l}\text { LM; IHC; IF; } \\
\text { EM }\end{array}$ & C3G and ATN \\
\hline
\end{tabular}

*: All patients were tested for SARS-CoV-2 and resulted in being positive on admission and at the time of the

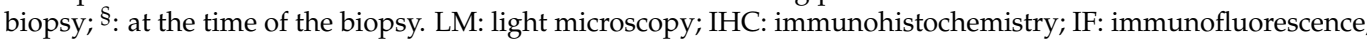
EM: electron microscopy; ATN: acute tubular necrosis; TMA: thrombotic microangiopathy; CG: collapsing glomerulopathy; MCD: minimal change disease; C3G: C3 glomerulonephritis.

\subsection{Acute Tubular Necrosis (ATN)}

Cases developing ATN were a male (Case 1) and a female (Case 2) in their 70s.

Case 1 had no features of glomerular injury apart from a focal and minimal ischemiarelated glomerulosclerosis, whereas the tubular compartment resulted in being seriously 
injured, presenting thinning and loss of apical cytoplasm and reactive nuclear atypia (Figure 1).

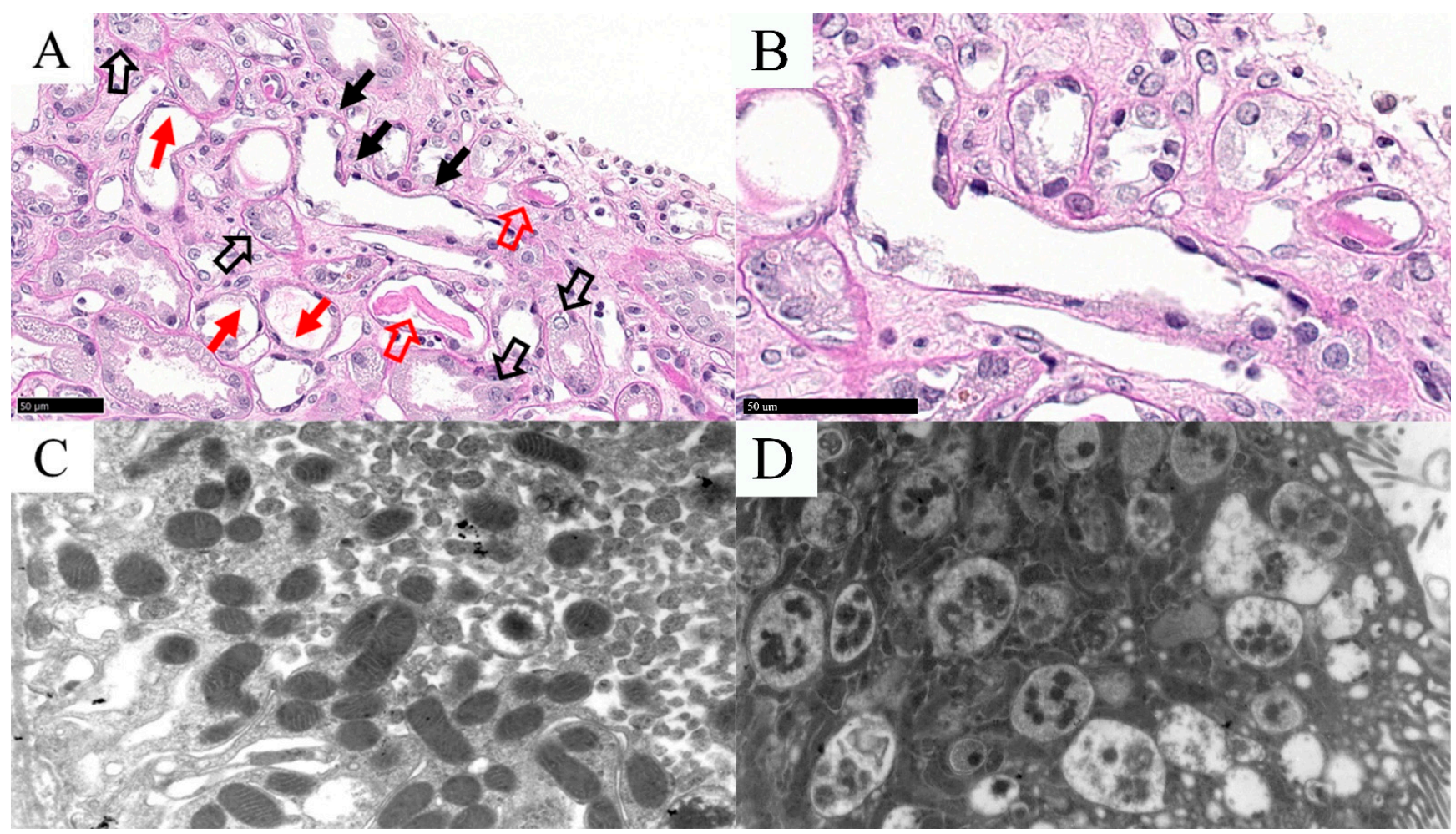

Figure 1. Histomorphological and ultrastructural features of Case 1. PAS stain (A) highlighted epithelial cell death (i.e., loss of or pale staining nuclei and eosinophilic cytoplasm; full black arrow), nuclei regenerative atypia (empty black arrow), and reduced or absent brush borders (full red arrow); eosinophilic casts in tubular lumens were also observed (empty red arrow) containing nuclear and cytoplasmic debris originated from necrotic tubular epithelial cells. Details of an injured tubules of the same area at high-power magnification (B). EM analysis confirmed the acute tubular injury showing mitochondrial condensation (C), and increased phagolysosomes (D).

IHC stains for C4d and SV40 were negative as well as IF analyses (i.e., immunoglobulin heavy-chains, complement fractions, and fibrinogen). Additionally, EM analysis was performed to exclude ultrastructural signs of chronic rejection (the patient underwent kidney transplantation two years before) and further confirmed the observed histopathological findings. EM had the characteristic features of ATN, such as tubular membrane apical blebs and shedding, mitochondrial condensation, and increased phagolysosomes (Figure 1). No viral particles were observed on EM, as well as no signs of chronic rejection (donor specific antibody (DSA) tested negative since the day of transplantation). Based on this evidence and according to the clinical history, a COVID-19-related ATN diagnosis was performed.

Case 2 also presented tubular features suggestive of ATN but with associated glomerular injury. Indeed, glomeruli showed a focally collapsed basement membrane, suggesting a mild glomerular microangiopathic injury (Figure 2).

IF showed a mild scattered finely granular positivity for $\mathrm{C} 3$ complement fragment that was considered unspecific (Figure 2). EM analysis identified segmental foot process effacement, and wrinkling of glomerular basement membrane with mild subendothelial electron-lucent widening and loss of endothelial cell fenestrae, thus confirming features of mild TMA glomerular injury (Figure 2). No electron-dense deposits and viral particles were observed on EM. Caveolin-1 (Cav1) immunohistochemistry demonstrated diffuse positivity both in peritubular and glomerular capillaries, as previously reported by our group in TMA [98]. 

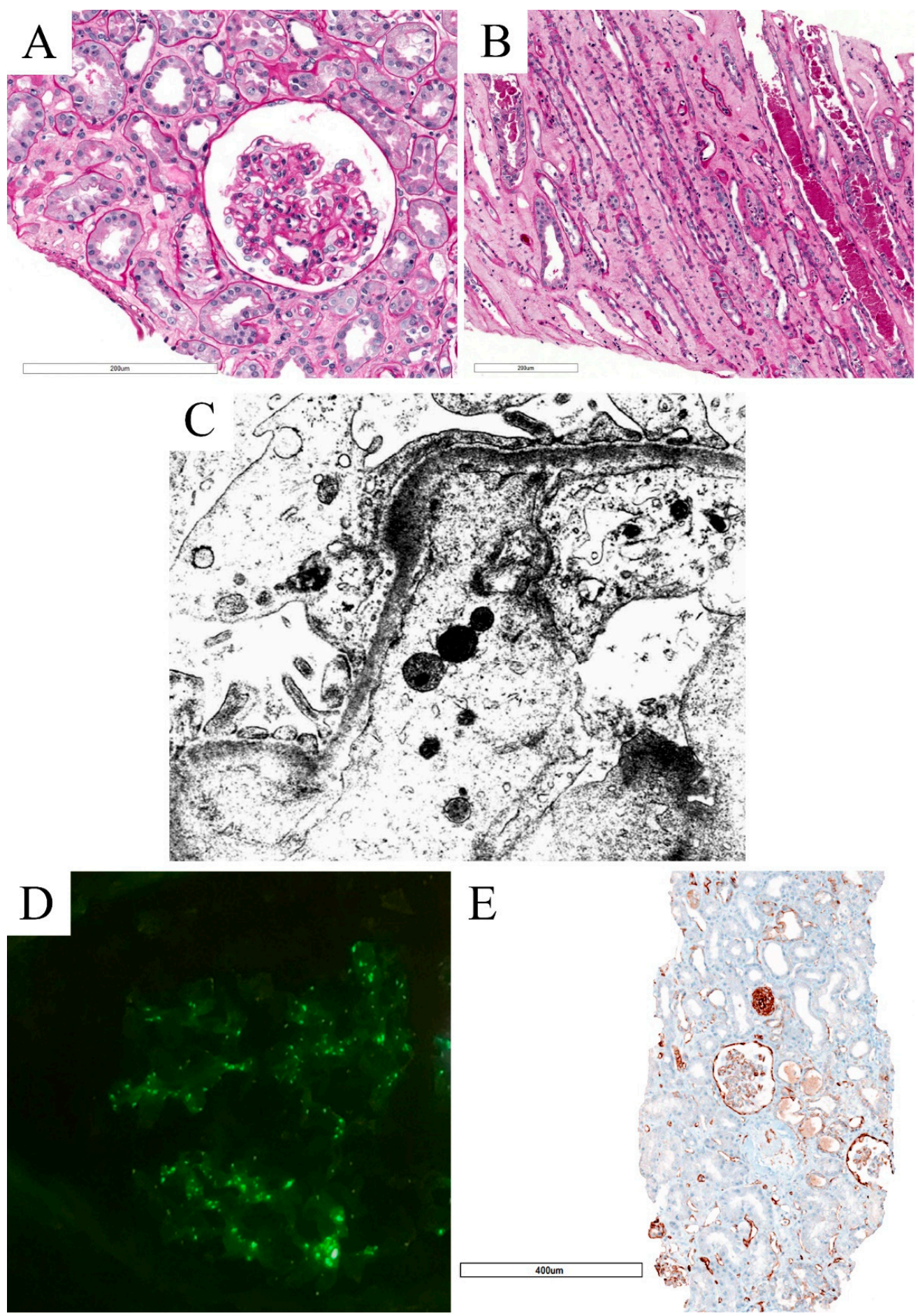

Figure 2. Histomorphological, IF, and ultrastructural features of Case 2. PAS stain (A,B) showing segmental wrinkling of glomerular basement membranes (A) and details of ATN (flattened epithelial cells and denudation of tubular basement membrane with necrotic material in lumen; (B). EM analysis showed segmental foot process effacement and confirmed the collapsed glomerular basement membrane with mild subendothelial space widening and loss of endothelial cell fenestrae $(\mathbf{C})$, whereas IF showed a mild and unspecific positivity for C3 (D). Cav1 immunohistochemistry showed diffuse positivity both in peritubular capillaries and glomeruli (E).

\subsection{Collapsing Glomerulopathy (CG)}

Two cases (Case 3 and Case 4) presented histopathological features of CG that affected two middle-aged Afro-American patients (61 and 45 years old, respectively). 
A kidney biopsy of Case 3 showed features of glomerular injury, such as global or segmental glomerular tuft collapse with several hypertrophic podocytes, rarely containing eosinophilic protein droplets (Figure 3).

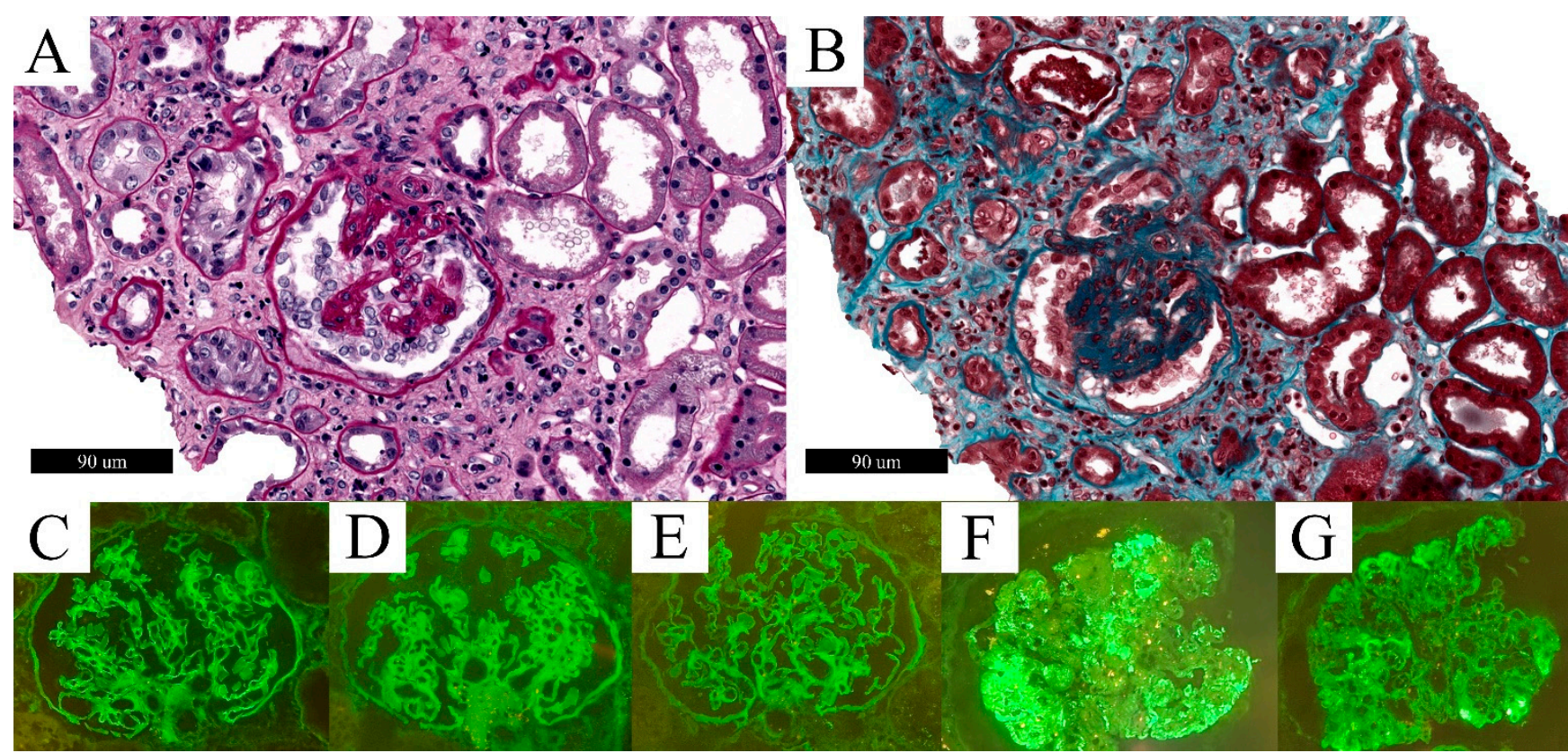

Figure 3. Histomorphological and IF features of Case 3. PAS stain (A) showed global collapse of glomerular tuft with overlying hypertrophy and hyperplasia of podocytes, highlighted by trichrome stain (B). IF showed mild and diffuse linear positivity for $\operatorname{IgG}(\mathbf{C})$, Lambda light chain (D), and Kappa light chain (E), while IgM (F) and C3 (G) were positive in sclerotic areas.

EM confirmed a glomerular segmental sclerosis (involving approximately $20 \%$ of capillary loops) characterized by the collapse of glomerular capillaries and prominent podocyte hypertrophy, and containing electron-dense protein resorption droplets and massive foot process effacement. There was also a diffuse thickening of glomerular basement membranes (mean thickness: $950 \mathrm{~nm}$ ) and a moderate mesangial matrix deposition. No electron-dense deposits nor viral particles were observed on EM. Overall, these features were consistent with a diagnosis of focal segmental glomerulosclerosis, collapsing variant, namely CG, with associated diabetic glomerulosclerosis (grade IIb according to Tervaert et al. [99]), confirmed by IF analysis (Figure 3). Indeed, IgG and Kappa and Lambda light chains showed a mild diffuse linear positivity of glomerular and tubular basement membrane on IF, whereas focal and segmental positivity for IgM, C3, and C1q was observed in sclerotic areas (Figure 3).

The kidney biopsy of Case 4 presented similar features, and was characterized by global or segmental glomerular capillary loop collapse with prominent podocyte hyperplasia and hypertrophy. Additionally, there was also a moderate acute tubular injury. IF stained slides could not be evaluated because only one single glomerulus with global sclerosis was present, whereas EM analysis could not be performed due to tissue exhaustion. Based on LM features and clinical data, a diagnosis of CG with associated moderate ATN features was rendered.

\subsection{Minimal Change Disease (MCD)}

Four cases presented MCD on kidney biopsy, none of them with significant or specific LM findings (Table 3). 
Table 3. Histomorphological and ultrastructural features of MCD.

\begin{tabular}{cccc}
\hline Cases & Histological Findings & IF Pattern & $\begin{array}{c}\text { EM Findings- } \\
\text { Percentage of Foot Process } \\
\text { Effacement (FPE) }\end{array}$ \\
\hline Case 5 & No evident injury & $\begin{array}{c}\text { Unspecific faint } \\
\text { mesangial IgM } \\
\text { positivity }\end{array}$ & $80 \%$ \\
\hline Case 6 & $\begin{array}{c}\text { Focal mild ischemic global } \\
\text { glomerulosclerosis age-correlated and } \\
\text { occasional nuclear tubular atypia }\end{array}$ & Negative & $77 \%$ \\
\hline Case 7 & $\begin{array}{c}\text { Minimal and focal glomerular } \\
\text { basement membrane wrinkling and } \\
\text { occasional nuclear tubular atypia }\end{array}$ & Negative & $75 \%$ \\
\hline Case 8 & No evident injury & Negative & $70-75 \%$ \\
\hline
\end{tabular}

Two cases presented mild age-related glomerulosclerosis and rare signs of ATN in the regenerative phase (Case 6), and minimal glomerular basement membrane wrinkling with occasional regenerative features of ATN (Case 7). Accordingly, no specific IF pattern was observed in any case. On EM analysis, all cases showed diffuse FPE involving up to $80 \%$ of glomerular capillary loops (Table 3) (Figure 4).

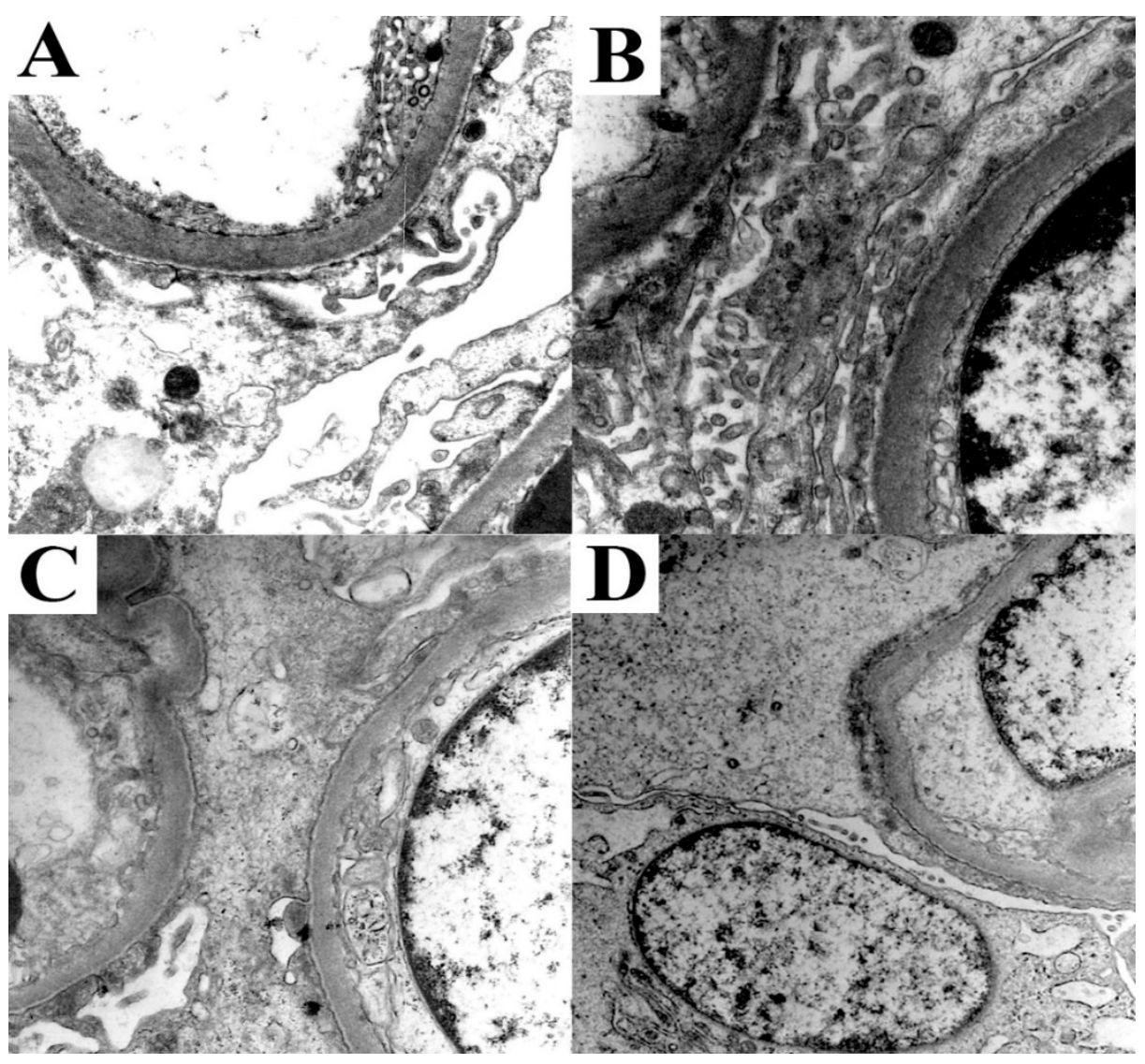

Figure 4. Ultrastructural features of MCD. Case 5 (A), Case 6 (B), Case 7 (C), and Case 8 (D) presented features of diffuse FPE.

\subsection{C3 Glomerulonephritis (C3G)}

The last case (Case 9) referred to a pediatric patient that presented C3G. In this case, fibroepithelial or cellular crescents were detected in $>50 \%$ of glomeruli (Figure 5). 


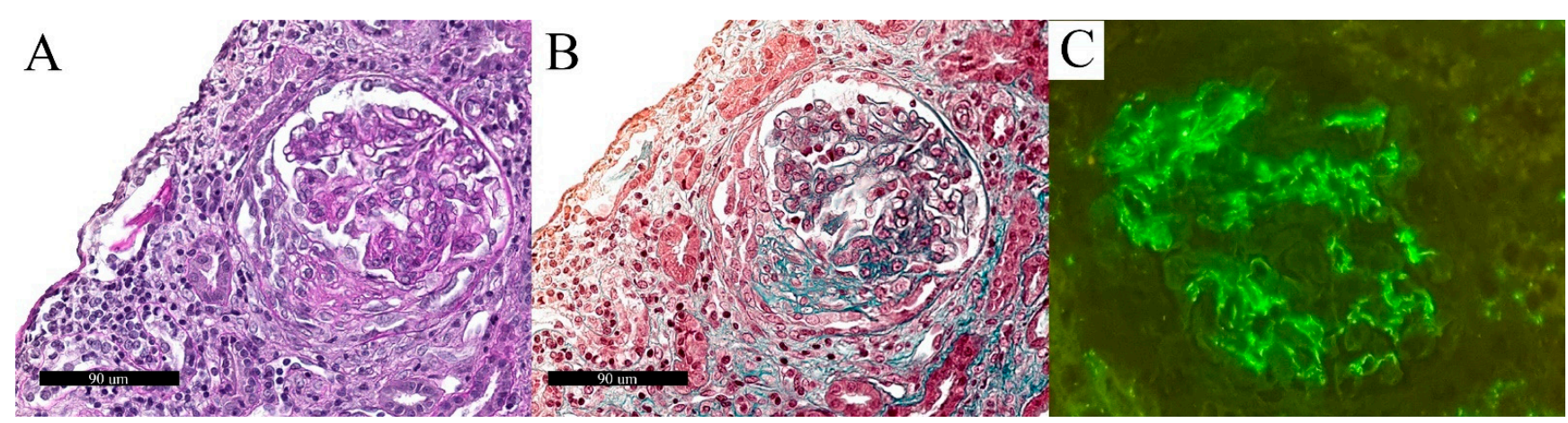

Figure 5. Histomorphological and IF features of Case 9. PAS stain (A) showed a glomerulus with fibrocellular crescent, highlighted by trichrome stain (B). IF for C3 was positive, showing a diffuse and strong granular positivity in glomerular basement membranes and mesangium (C).

Crescents were either circumferential, leading to global glomeruli collapse, or partial, inducing segmental collapsed glomeruli basement membranes (Figure 5). We also observed focal features of ATN in the presence of erythrocyte casts. IF demonstrated diffusely and strongly granular positivity for $\mathrm{C} 3$ in glomerular basement membranes and mesangium (Figure 5). C4d IHC stain resulted negative, further confirming the activation of the alternative complement pathway. EM analysis showed amorphous deposits, mainly localized in mesangial and paramesangial areas and characterized by intermediate density and sometimes indistinct borders (Figure 5). No viral particles were observed on EM. Based on these findings and according to the clinical background, the diagnosis of C3G was established.

\section{Discussion}

This study described the pathology findings of COVID-19-associated kidney injury reported in our institution since the pandemic outbreak, thus depicting the main morphologic, immunofluorescence, and ultrastructure features we reported in our daily diagnostic routine. In particular, we (1) confirmed the kidney involvement during SARS-CoV-2 infection, affecting all ages and both native and transplanted organs regardless of lung symptoms, (2) highlighted the relevance of clinical correlation rather than the presence of viral particles/molecular evidence to diagnose COVID-19-related kidney injury, (3) described patterns of kidney injury as previously observed (i.e., ATN and CG), and (4) reported additional forms of kidney involvement during COVID-19 (i.e., MCD and C3G).

Clinical correlation is crucial to define and properly characterize kidney involvement during COVID-19. At first, COVID-19 emerged as an acute condition targeting the lungs and mainly affecting adult patients. To date, we know that the disease is more multifaceted, presenting a wide range of symptom severity and affecting all ages. In addition, several organs are involved but the kidney has emerged as a peculiar site of injury. Indeed, in a prospective cohort study enrolling approximatively 700 patients, Cheng et al. observed that more than $40 \%$ of COVID-19 hospitalized patients presented evidence of kidney injury and further reported that, similarly to H1N1 influenza A virus and SARS-CoV, AKI resulted in an independent risk factor for hospital mortality [46]. Similarly, Chan et al. reported that $46 \%$ of 3993 COVID-19 hospitalized patients in the US developed AKI, whereas 19\% required kidney replacement therapy [53]. Data published by Karagiannidis et al. from a multicentric German cohort of 10,021 COVID-19 hospitalized patients reported a renal failure rate of $23 \%$ and dialysis percentage ranging from $6 \%$ (all patients) to $27 \%$ (within the ventilated patient subgroup) [54].

Further addressing the renal involvement during COVID-19, two considerations are noteworthy. Firstly, COVID-19 could manifest with extrapulmonary symptoms only and, in particular, with signs of kidney involvement in an otherwise clinically silent setting [63]. Although our study focused on histomorphological features, most cases did not present lung-related symptoms or an abrupt manifestation during the disease. This finding is 
particularly relevant to properly define the role of SARS-CoV-2 in determining kidney injury and eventually prevent delayed diagnosis. The tropism of SARS-CoV-2 for renal cells was initially assumed based on the well-documented elevated expression of ACE-2 receptor in the kidney, but recent findings suggested additional (and probably more relevant) mechanisms of damage, such as cytokine storm, immune complexes deposition, and (micro) vascular dysfunction $[24,33,34]$. Indeed, although some case reports and autopsy findings reported putative SARS-CoV-2 particles on EM kidney analysis [72,100], further studies addressing both ultrastructural and molecular evidence of the virus excluded its direct presence in kidney sites of injury [58,76,96,101-105]. Accordingly, we did not observe any viral or viral-like particles on EM analysis, thus supporting the emerging concept that the direct demonstration of viral presence, either ultrastructural or molecular, should not be considered mandatory to diagnose a COVID-19-related kidney injury, whereas temporal and clinical correlation proved to be more relevant.

This is significant evidence, as it could refine the concept of COVID-19-related kidney involvement, thus identifying all the morphological patterns associated with SARS-CoV-2 infection and ultimately improving the diagnosis and clinical management of affected patients. Secondly, we confirmed the renal impairment in the pediatric population. Pediatric manifestations of SARS-CoV-2-mediated kidney injury are poorly described. Based on published data, the clinical scenario did not differ substantially from the adult setting, thus presenting high rates (up to 37\%) of AKI development, thrombotic microangiopathy, and acute necrotizing glomerulopathy [106-112]. Our series, although limited, included two pediatric patients that presented unusual patterns of SARS-CoV-2 pediatric injury, namely MCD and C3G. In the pediatric population, MCD is primarily associated with nephrotic syndrome [113] and is characterized by diffuse FPE on EM analysis, combined with the almost complete absence of LM findings and the unspecific focal IF expression of IgM, as we observed in our pediatric MCD case. MCD etiopathogenesis is mainly idiopathic, but it could be secondary to different pathologies, including viral infection, as reported for COVID-19 hospitalized adult patients [56,71,80,114]. Indeed, MCD could develop following a "two-hit" mechanism characterized by podocytes increased and unregulated CD80 expression that is triggered by viral products [115-117].

Similarly, C3G could also be related to viral infection. C3G is part of the primary membranoproliferative glomerulonephritis, a group of pathologies recently re-classified to properly represent the etiopathogenesis and improve the subsequent treatment accordingly [118]. C3G could manifest as a nephritic or nephrotic syndrome, but the most common clinical presentation is asymptomatic hematuria or proteinuria $(60 \%$ of cases, approximatively) $[119,120]$, as observed in our case. Pathognomonic features of this condition were represented by LM-evident glomerular deposition further characterized as an intense C3-positive IF pattern associated with electron-dense deposits on EM. Accordingly, these features characterized the C3G COVID-19-related case reported in this study.

These cases are of particular interest, as they expand our current knowledge of COVID19-related pediatric kidney diseases. Overall, COVID-19 pediatric cases showed excellent outcomes compared to adults as they are characterized by reduced incidence of acute organ failure (less than 1\% of hospitalized patients, approximatively) [111,121-127]. However, children experiencing COVID-19 presented a clinically subtle kidney involvement that was challenging to recognize and diagnose, particularly in extrapulmonary-only clinical settings [111]. Importantly, misdiagnosing kidney injury in the pediatric population is likely to lead to delayed treatment and increased development of long-term complications. In the adult setting, COVID-19-related kidney injury started being increasingly reported as a heterogeneous and evolving scenario, but two histomorphological features emerged as particularly relevant, namely ATN and CG. ATN is referred to as reversible destruction of the excretory compartment of the kidney, the tubules. Several conditions could lead to ATN, but two significant groups were usually described: (1) ischemia-related, as observed during marked hypotension/shock conditions, such as acute pancreatitis and trauma, and (2) nephrotoxic-related agents (e.g., drugs (gentamycin, cisplatin, methotrex- 
ate), hemoglobin, myoglobin). As per the COVID-19 infection, ATN nowadays represents a well-described complication of COVID-19 hospitalized patients and the most common histomorphological pattern leading to AKI [101,128-135]. In our series, we observed a relevant rate of ATN in different phases (from active necrosis to later regenerative stages), and, according to the literature, it was the main pattern related to AKI. ATN diagnosis is mainly LM-based and characterized by a severe involvement of the tubule and a relative sparing of the glomerular compartment, as observed in our series. Of note, one of our ATN cases was observed in a kidney-transplant patient. COVID-19 effects on transplant patients are particularly relevant, as these patients are treated with chronic immunosuppression protocols and usually harbored individual predisposing factors for kidney injury [136]. In particular, COVID-19 kidney-transplant recipients showed worse outcomes than the general populations, characterized by a more aggressive clinical course and an increased mortality rate [38,64,104,136-138]. From a pathology perspective, the biopsy findings consistently showed features of rejection, particularly acute rejection (both cellular and antibody-mediated), or transplant-related condition, such as calcineurin toxicity $[64,136,138]$. In contrast, we did not report any morphological and ultrastructural sign of rejection, but rather features of tubular injury and necrosis, further supporting the aggressive course in the transplant subgroup of patients.

CG is an additional and relevant emerging condition associated with COVID-19 disease with crucial clinical implications [63]. Indeed, CG represented a rapidly degenerative subset of focal segmental glomerulosclerosis leading to nephrotic syndrome, organ dysfunction, and renal failure. CG was particularly related to the Afro-American ancestry due to a characteristic apolipoprotein L1 gene polymorphism and is mainly caused by a viral-related inflammatory cascade [139]. Of note, CG etiopathogenesis, pathology features, and the rise of incidence observed during the COVID-19 pandemic has led to the definition of COVID-19-associated nephropathy (COVAN) due to the resemblance with the features observed during the HIV pandemic [63,72,76,140]. The main histomorphological findings of CG are glomerular collapse (either global or segmental) together with podocyte hyperplasia and hypertrophy, with IgM and C3 in sclerotic areas on IF analysis. EM proved helpful in confirming glomerular involvement as capillary loop collapse and diffuse FPE. In our series, we confirmed both the pathology findings and demographic trend, considering that the currently reported cases of CG occurred in Afro-American patients.

To address our study limitations, mainly represented by the small sample size and the limited insights on injury mechanistic, further studies should explore multicentric larger series providing more granular molecular analysis and identifying the specific pathways activated during COVID-19-related kidney injury.

\section{Conclusions}

COVID-19 is a constantly evolving disease, and new variants of SARS-CoV-2 are being reported. Kidney manifestations of COVID-19 should be carefully and specifically diagnosed to guide patient clinical management and prevent chronic organ injury, particularly considering the fragile subgroups of patients (e.g., pediatric and transplanted populations) that could be affected and the relatively poor direct signs of viral infection (i.e., viral particles/molecular footprint) in tissue samples.

Supplementary Materials: The following are available online at https:/ / www.mdpi.com/article/ 10.3390/biom12020298/s1. Supplementary Methods: IHC and IF protocols and procedures.

Author Contributions: Conceptualization, A.B. and P.C.; data curation, A.G., A.B. and L.B. (Luigi Biancone), D.R., L.P. and L.B. (Luca Besso), C.L., A.A., M.P. and P.C.; formal analysis, A.G.; methodology, A.G. and A.B.; supervision, A.B., L.B. (Luigi Biancone), D.R., L.P., L.B. (Luca Besso), C.L., A.A., M.P. and P.C.; writing-original draft, A.G. and A.B.; Writing-review and editing, A.G., A.B., L.B. (Luigi Biancone), D.R., L.P., L.B. (Luca Besso), C.L., A.A., M.P. and P.C. All authors have read and agreed to the published version of the manuscript.

Funding: This research received no external funding. 
Institutional Review Board Statement: The study was conducted according to the guidelines of the Declaration of Helsinki; ethical review and approval were waived for this study, due to the study type.

Informed Consent Statement: Patient consent was waived due to the retrospective nature of the study.

Data Availability Statement: The data presented in this study are available on request from the corresponding author. The data are not publicly available due to privacy restriction.

Conflicts of Interest: The authors declare no conflict of interest.

\section{References}

1. Saied, E.M.; El-Maradny, Y.A.; Osman, A.A.; Darwish, A.M.G.; Abo Nahas, H.H.; Niedbala, G.; Piekutowska, M.; AbdelRahman, M.A.; Balbool, B.A.; Abdel-Azeem, A.M. A Comprehensive Review about the Molecular Structure of Severe Acute Respiratory Syndrome Coronavirus 2 (SARS-CoV-2): Insights into Natural Products against COVID-19. Pharmaceutics 2021, 13, 1759. [CrossRef] [PubMed]

2. Kayode, A.J.; Banji-Onisile, F.O.; Olaniran, A.O.; Okoh, A.I. An Overview of the Pathogenesis, Transmission, Diagnosis, and Management of Endemic Human Coronaviruses: A Reflection on the Past and Present Episodes and Possible Future Outbreaks. Pathogens 2021, 10, 1108. [CrossRef]

3. Barth, R.F.; Buja, L.M.; Barth, A.L.; Carpenter, D.E.; Parwani, A.V. A Comparison of the Clinical, Viral, Pathologic, and Immunologic Features of Severe Acute Respiratory Syndrome (SARS), Middle East Respiratory Syndrome (MERS), and Coronavirus 2019 (COVID-19) Diseases. Arch. Pathol. Lab. Med. 2021, 145, 1194-1211. [CrossRef] [PubMed]

4. Churruca, M.; Martinez-Besteiro, E.; Counago, F.; Landete, P. COVID-19 pneumonia: A review of typical radiological characteristics. World J. Radiol. 2021, 13, 327-343. [CrossRef] [PubMed]

5. Verma, H.K. Radiological and clinical spectrum of COVID-19: A major concern for public health. World J. Radiol. 2021, 13, 53-63. [CrossRef]

6. AlSamman, M.; Caggiula, A.; Ganguli, S.; Misak, M.; Pourmand, A. Non-respiratory presentations of COVID-19, a clinical review. Am. J. Emerg. Med. 2020, 38, 2444-2454. [CrossRef]

7. Enitan, A.O.; Olasode, O.A. The Cutaneous Manifestations of COVID-19: A Review of Emerging Literature. West. Afr. J. Med. 2020, 37, 569-573.

8. Divani, A.A.; Andalib, S.; Biller, J.; Di Napoli, M.; Moghimi, N.; Rubinos, C.A.; Nobleza, C.O.; Sylaja, P.N.; Toledano, M.; Lattanzi, S.; et al. Central Nervous System Manifestations Associated with COVID-19. Curr. Neurol. Neurosci. Rep. 2020, 20, 60. [CrossRef]

9. Wu, Z.H.; Yang, D.L. A meta-analysis of the impact of COVID-19 on liver dysfunction. Eur. J. Med. Res. 2020, 25, 54. [CrossRef]

10. Lei, H.Y.; Ding, Y.H.; Nie, K.; Dong, Y.M.; Xu, J.H.; Yang, M.L.; Liu, M.Q.; Wei, L.; Nasser, M.I.; Xu, L.Y.; et al. Potential effects of SARS-CoV-2 on the gastrointestinal tract and liver. Biomed. Pharmacother. 2021, 133, 111064. [CrossRef]

11. De Giorgio, M.R.; Di Noia, S.; Morciano, C.; Conte, D. The impact of SARS-CoV-2 on skeletal muscles. Acta Myol. 2020, 39, 307-312. [CrossRef]

12. Harapan, B.N.; Yoo, H.J. Neurological symptoms, manifestations, and complications associated with severe acute respiratory syndrome coronavirus 2 (SARS-CoV-2) and coronavirus disease 19 (COVID-19). J. Neurol. 2021, 268, 3059-3071. [CrossRef] [PubMed]

13. Capaccione, K.M.; Yang, H.; West, E.; Patel, H.; Ma, H.; Patel, S.; Fruauff, A.; Loeb, G.; Maddocks, A.; Borowski, A.; et al Pathophysiology and Imaging Findings of COVID-19 Infection: An Organ-system Based Review. Acad. Radiol. 2021, $28,595-607$. [CrossRef] [PubMed]

14. Gattinoni, L.; Gattarello, S.; Steinberg, I.; Busana, M.; Palermo, P.; Lazzari, S.; Romitti, F.; Quintel, M.; Meissner, K.; Marini, J.J.; et al. COVID-19 pneumonia: Pathophysiology and management. Eur. Respir. Rev. 2021, 30, 210138. [CrossRef] [PubMed]

15. Parker, A.M.; Brigham, E.; Connolly, B.; McPeake, J.; Agranovich, A.V.; Kenes, M.T.; Casey, K.; Reynolds, C.; Schmidt, K.F.R.; Kim, S.Y.; et al. Addressing the post-acute sequelae of SARS-CoV-2 infection: A multidisciplinary model of care. Lancet Respir. Med. 2021, 9, 1328-1341. [CrossRef]

16. Neta, F.I.; Fernandes, A.C.L.; Vale, A.J.M.; Pinheiro, F.I.; Cobucci, R.N.; Azevedo, E.P.; Guzen, F.P. Pathophysiology and possible treatments for olfactory-gustatory disorders in patients affected by COVID-19. Curr. Res. Pharmacol. Drug Discov. 2021, $2,100035$. [CrossRef]

17. Liang, F.; Wang, Y. COVID-19 Anosmia: High Prevalence, Plural Neuropathogenic Mechanisms, and Scarce Neurotropism of SARS-CoV-2? Viruses 2021, 13, 2225. [CrossRef]

18. Zhang, J.; Garrett, S.; Sun, J. Gastrointestinal symptoms, pathophysiology, and treatment in COVID-19. Genes Dis. 2021, 8, 385-400 [CrossRef]

19. Groff, A.; Kavanaugh, M.; Ramgobin, D.; McClafferty, B.; Aggarwal, C.S.; Golamari, R.; Jain, R. Gastrointestinal Manifestations of COVID-19: A Review of What We Know. Ochsner J. 2021, 21, 177-180. [CrossRef]

20. Bodro, M.; Compta, Y.; Sanchez-Valle, R. Presentations and mechanisms of CNS disorders related to COVID-19. Neurol. Neuroimmunol. Neuroinflamm. 2021, 8, e923. [CrossRef] 
21. Li, M.; Chen, S.; Xiang, X.; Wang, Q.; Liu, X. Effects of SARS-CoV-2 and its functional receptor ACE2 on the cardiovascular system. Herz 2020, 45, 659-662. [CrossRef] [PubMed]

22. Dhakal, B.P.; Sweitzer, N.K.; Indik, J.H.; Acharya, D.; William, P. SARS-CoV-2 Infection and Cardiovascular Disease: COVID-19 Heart. Heart Lung Circ. 2020, 29, 973-987. [CrossRef] [PubMed]

23. Liu, K.; Chen, X.; Ren, X.; Wu, Y.; Ren, S.; Qin, C. SARS-CoV-2 effects in the genitourinary system and prospects of sex hormone therapy. Asian J. Urol. 2021, 8, 303-314. [CrossRef] [PubMed]

24. Gupta, A.; Madhavan, M.V.; Sehgal, K.; Nair, N.; Mahajan, S.; Sehrawat, T.S.; Bikdeli, B.; Ahluwalia, N.; Ausiello, J.C.; Wan, E.Y.; et al. Extrapulmonary manifestations of COVID-19. Nat. Med. 2020, 26, 1017-1032. [CrossRef] [PubMed]

25. Mokhtari, T.; Hassani, F.; Ghaffari, N.; Ebrahimi, B.; Yarahmadi, A.; Hassanzadeh, G. COVID-19 and multiorgan failure: A narrative review on potential mechanisms. J. Mol. Histol. 2020, 51, 613-628. [CrossRef] [PubMed]

26. Hamming, I.; Timens, W.; Bulthuis, M.L.; Lely, A.T.; Navis, G.; van Goor, H. Tissue distribution of ACE2 protein, the functional receptor for SARS coronavirus. A first step in understanding SARS pathogenesis. J. Pathol. 2004, 203, 631-637. [CrossRef]

27. Benton, D.J.; Wrobel, A.G.; Xu, P.; Roustan, C.; Martin, S.R.; Rosenthal, P.B.; Skehel, J.J.; Gamblin, S.J. Receptor binding and priming of the spike protein of SARS-CoV-2 for membrane fusion. Nature 2020, 588, 327-330. [CrossRef]

28. Lan, J.; Ge, J.; Yu, J.; Shan, S.; Zhou, H.; Fan, S.; Zhang, Q.; Shi, X.; Wang, Q.; Zhang, L.; et al. Structure of the SARS-CoV-2 spike receptor-binding domain bound to the ACE2 receptor. Nature 2020, 581, 215-220. [CrossRef]

29. Shang, J.; Ye, G.; Shi, K.; Wan, Y.; Luo, C.; Aihara, H.; Geng, Q.; Auerbach, A.; Li, F. Structural basis of receptor recognition by SARS-CoV-2. Nature 2020, 581, 221-224. [CrossRef]

30. Li, W.; Moore, M.J.; Vasilieva, N.; Sui, J.; Wong, S.K.; Berne, M.A.; Somasundaran, M.; Sullivan, J.L.; Luzuriaga, K.; Greenough, T.C.; et al. Angiotensin-converting enzyme 2 is a functional receptor for the SARS coronavirus. Nature 2003, 426, 450-454. [CrossRef]

31. Soler, M.J.; Wysocki, J.; Batlle, D. Angiotensin-converting enzyme 2 and the kidney. Exp. Physiol. 2008, 93, 549-556. [CrossRef] [PubMed]

32. Koitka, A.; Cooper, M.E.; Thomas, M.C.; Tikellis, C. Angiotensin converting enzyme 2 in the kidney. Clin. Exp. Pharmacol. Physiol. 2008, 35, 420-425. [CrossRef] [PubMed]

33. Pan, X.W.; Xu, D.; Zhang, H.; Zhou, W.; Wang, L.H.; Cui, X.G. Identification of a potential mechanism of acute kidney injury during the COVID-19 outbreak: A study based on single-cell transcriptome analysis. Intensive Care Med. 2020, 46, 1114-1116. [CrossRef] [PubMed]

34. Varga, Z.; Flammer, A.J.; Steiger, P.; Haberecker, M.; Andermatt, R.; Zinkernagel, A.S.; Mehra, M.R.; Schuepbach, R.A.; Ruschitzka, F.; Moch, H. Endothelial cell infection and endotheliitis in COVID-19. Lancet 2020, 395, 1417-1418. [CrossRef]

35. Contributors to the C4 Article. C4 article: Implications of COVID-19 in transplantation. Am. J. Transplant. 2021, 21, 1801-1815. [CrossRef]

36. Glowacka, M.; Lipka, S.; Mlynarska, E.; Franczyk, B.; Rysz, J. Acute Kidney Injury in COVID-19. Int. J. Mol. Sci. $2021,22,8081$. [CrossRef] [PubMed]

37. Kaye, A.D.; Okeagu, C.N.; Tortorich, G.; Pham, A.D.; Ly, E.I.; Brondeel, K.C.; Eng, M.R.; Luedi, M.M.; Urman, R.D.; Cornett, E.M COVID-19 impact on the renal system: Pathophysiology and clinical outcomes. Best Pract. Res. Clin. Anaesthesiol. 2021, 35, 449-459. [CrossRef]

38. Bruchfeld, A. The COVID-19 pandemic: Consequences for nephrology. Nat. Rev. Nephrol. 2021, 17, 81-82. [CrossRef]

39. Caillard, S.; Thaunat, O. COVID-19 vaccination in kidney transplant recipients. Nat. Rev. Nephrol. 2021, 17, 785-787. [CrossRef]

40. Windpessl, M.; Bruchfeld, A.; Anders, H.J.; Kramer, H.; Waldman, M.; Renia, L.; Ng, L.F.P.; Xing, Z.; Kronbichler, A. COVID-19 vaccines and kidney disease. Nat. Rev. Nephrol. 2021, 17, 291-293. [CrossRef]

41. Kronbichler, A.; Gauckler, P.; Windpessl, M.; Il Shin, J.; Jha, V.; Rovin, B.H.; Oberbauer, R. COVID-19: Implications for immunosuppression in kidney disease and transplantation. Nat. Rev. Nephrol. 2020, 16, 365-367. [CrossRef]

42. Nadim, M.K.; Forni, L.G.; Mehta, R.L.; Connor, M.J., Jr.; Liu, K.D.; Ostermann, M.; Rimmele, T.; Zarbock, A.; Bell, S.; Bihorac, A.; et al. COVID-19-associated acute kidney injury: Consensus report of the 25th Acute Disease Quality Initiative (ADQI) Workgroup. Nat. Rev. Nephrol. 2020, 16, 747-764. [CrossRef]

43. Zaman, M.S.; Sizemore, R.C. Diverse Manifestations of COVID-19: Some Suggested Mechanisms. Int. J. Environ. Res. Public Health 2021, 18, 9785. [CrossRef]

44. Perico, L.; Benigni, A.; Casiraghi, F.; Ng, L.F.P.; Renia, L.; Remuzzi, G. Immunity, endothelial injury and complement-induced coagulopathy in COVID-19. Nat. Rev. Nephrol. 2021, 17, 46-64. [CrossRef] [PubMed]

45. Alasfar, S.; Avery, R.K. The impact of COVID-19 on kidney transplantation. Nat. Rev. Nephrol. 2020, 16, 568-569. [CrossRef]

46. Cheng, Y.; Luo, R.; Wang, K.; Zhang, M.; Wang, Z.; Dong, L.; Li, J.; Yao, Y.; Ge, S.; Xu, G. Kidney disease is associated with in-hospital death of patients with COVID-19. Kidney Int. 2020, 97, 829-838. [CrossRef] [PubMed]

47. Allison, S. Kidney involvement in COVID-19. Nat. Rev. Nephrol. 2021, 17, 572. [CrossRef]

48. Ronco, C.; Reis, T. Kidney involvement in COVID-19 and rationale for extracorporeal therapies. Nat. Rev. Nephrol. 2020, 16, 308-310. [CrossRef]

49. Yende, S.; Parikh, C.R. Long COVID and kidney disease. Nat. Rev. Nephrol. 2021, 17, 792-793. [CrossRef] [PubMed]

50. Shah, M.D.; Sumeh, A.S.; Sheraz, M.; Kavitha, M.S.; Venmathi Maran, B.A.; Rodrigues, K.F. A mini-review on the impact of COVID 19 on vital organs. Biomed. Pharmacother. 2021, 143, 112158. [CrossRef] 
51. Legrand, M.; Bell, S.; Forni, L.; Joannidis, M.; Koyner, J.L.; Liu, K.; Cantaluppi, V. Pathophysiology of COVID-19-associated acute kidney injury. Nat. Rev. Nephrol. 2021, 17, 751-764. [CrossRef]

52. George, J.A.; Khoza, S. SARS-CoV-2 Infection and the Kidneys: An Evolving Picture. Adv. Exp. Med. Biol. 2021, 1327, 107-118. [CrossRef]

53. Chan, L.; Chaudhary, K.; Saha, A.; Chauhan, K.; Vaid, A.; Zhao, S.; Paranjpe, I.; Somani, S.; Richter, F.; Miotto, R.; et al. AKI in Hospitalized Patients with COVID-19. J. Am. Soc. Nephrol. 2021, 32, 151-160. [CrossRef]

54. Karagiannidis, C.; Mostert, C.; Hentschker, C.; Voshaar, T.; Malzahn, J.; Schillinger, G.; Klauber, J.; Janssens, U.; Marx, G.; Weber-Carstens, S.; et al. Case characteristics, resource use, and outcomes of 10021 patients with COVID-19 admitted to 920 German hospitals: An observational study. Lancet Respir. Med. 2020, 8, 853-862. [CrossRef]

55. Kesiena, O.; Papadopoulos, P.; Amakye, D.; Hama, E.; Mackay, R. COVID-19 associated collapsing glomerulopathy presenting as acute kidney injury on chronic kidney disease: A case report and review of the literature. CEN Case Rep. 2021. [CrossRef] [PubMed]

56. Kudose, S.; Santoriello, D.; Bomback, A.S.; Sekulic, M.; Batal, I.; Stokes, M.B.; Ghavami, I.A.; Kim, J.S.; Marasa, M.; Xu, K.; et al. Longitudinal Outcomes of COVID-19-Associated Collapsing Glomerulopathy and Other Podocytopathies. J. Am. Soc. Nephrol. 2021, 32, 2958-2969. [CrossRef]

57. Sharma, Y.; Nasr, S.H.; Larsen, C.P.; Kemper, A.; Ormsby, A.H.; Williamson, S.R. COVID-19-Associated Collapsing Focal Segmental Glomerulosclerosis: A Report of 2 Cases. Kidney Med. 2020, 2, 493-497. [CrossRef] [PubMed]

58. Sharma, P.; Uppal, N.N.; Wanchoo, R.; Shah, H.H.; Yang, Y.; Parikh, R.; Khanin, Y.; Madireddy, V.; Larsen, C.P.; Jhaveri, K.D.; et al. COVID-19-Associated Kidney Injury: A Case Series of Kidney Biopsy Findings. J. Am. Soc. Nephrol. 2020, 31, 1948-1958. [CrossRef] [PubMed]

59. Sharma, P.; Ng, J.H.; Bijol, V.; Jhaveri, K.D.; Wanchoo, R. Pathology of COVID-19-associated acute kidney injury. Clin. Kidney J. 2021, 14, i30-i39. [CrossRef]

60. Smith, K.D.; Akilesh, S. Pathogenesis of coronavirus disease 2019-associated kidney injury. Curr. Opin. Nephrol. Hypertens 2021, 30, 324-331. [CrossRef]

61. Izzedine, H.; Brocheriou, I.; Arzouk, N.; Seilhean, D.; Couvert, P.; Cluzel, P.; Pha, M.; Le Monnier, O.; Varnous, S.; Andreelli, F.; et al. COVID-19-associated collapsing glomerulopathy: A report of two cases and literature review. Intern. Med. J. 2020, 50, 1551-1558. [CrossRef] [PubMed]

62. Shetty, A.A.; Tawhari, I.; Safar-Boueri, L.; Seif, N.; Alahmadi, A.; Gargiulo, R.; Aggarwal, V.; Usman, I.; Kisselev, S.; Gharavi, A.G.; et al. COVID-19-Associated Glomerular Disease. J. Am. Soc. Nephrol. 2021, 32, 33-40. [CrossRef]

63. Nasr, S.H.; Kopp, J.B. COVID-19-Associated Collapsing Glomerulopathy: An Emerging Entity. Kidney Int. Rep. $2020,5,759-761$. [CrossRef]

64. Akilesh, S.; Nast, C.C.; Yamashita, M.; Henriksen, K.; Charu, V.; Troxell, M.L.; Kambham, N.; Bracamonte, E.; Houghton, D.; Ahmed, N.I.; et al. Multicenter Clinicopathologic Correlation of Kidney Biopsies Performed in COVID-19 Patients Presenting With Acute Kidney Injury or Proteinuria. Am. J. Kidney Dis. 2021, 77, 82-93 e81. [CrossRef] [PubMed]

65. Elsoukkary, S.S.; Mostyka, M.; Dillard, A.; Berman, D.R.; Ma, L.X.; Chadburn, A.; Yantiss, R.K.; Jessurun, J.; Seshan, S.V.; Borczuk, A.C.; et al. Autopsy Findings in 32 Patients with COVID-19: A Single-Institution Experience. Pathobiology 2021, 88, 56-68. [CrossRef]

66. Ferlicot, S.; Jamme, M.; Gaillard, F.; Oniszczuk, J.; Couturier, A.; May, O.; Grunenwald, A.; Sannier, A.; Moktefi, A.; Le Monnier, O.; et al. The spectrum of kidney biopsies in hospitalized patients with COVID-19, acute kidney injury, and/or proteinuria. Nephrol. Dial. Transplant. 2021, 36, 1253-1262. [CrossRef]

67. Jhaveri, K.D.; Meir, L.R.; Flores Chang, B.S.; Parikh, R.; Wanchoo, R.; Barilla-LaBarca, M.L.; Bijol, V.; Hajizadeh, N. Thrombotic microangiopathy in a patient with COVID-19. Kidney Int. 2020, 98, 509-512. [CrossRef] [PubMed]

68. Golmai, P.; Larsen, C.P.; DeVita, M.V.; Wahl, S.J.; Weins, A.; Rennke, H.G.; Bijol, V.; Rosenstock, J.L. Histopathologic and Ultrastructural Findings in Postmortem Kidney Biopsy Material in 12 Patients with AKI and COVID-19. J. Am. Soc. Nephrol. 2020, 31, 1944-1947. [CrossRef]

69. May, R.M.; Cassol, C.; Hannoudi, A.; Larsen, C.P.; Lerma, E.V.; Haun, R.S.; Braga, J.R.; Hassen, S.I.; Wilson, J.; VanBeek, C.; et al. A multi-center retrospective cohort study defines the spectrum of kidney pathology in Coronavirus 2019 Disease (COVID-19). Kidney Int. 2021, 100, 1303-1315. [CrossRef]

70. Peleg, Y.; Kudose, S.; D'Agati, V.; Siddall, E.; Ahmad, S.; Nickolas, T.; Kisselev, S.; Gharavi, A.; Canetta, P. Acute Kidney Injury Due to Collapsing Glomerulopathy Following COVID-19 Infection. Kidney Int. Rep. 2020, 5, 940-945. [CrossRef] [PubMed]

71. Kudose, S.; Batal, I.; Santoriello, D.; Xu, K.; Barasch, J.; Peleg, Y.; Canetta, P.; Ratner, L.E.; Marasa, M.; Gharavi, A.G.; et al. Kidney Biopsy Findings in Patients with COVID-19. J. Am. Soc. Nephrol. 2020, 31, 1959-1968. [CrossRef] [PubMed]

72. Kissling, S.; Rotman, S.; Gerber, C.; Halfon, M.; Lamoth, F.; Comte, D.; Lhopitallier, L.; Sadallah, S.; Fakhouri, F. Collapsing glomerulopathy in a COVID-19 patient. Kidney Int. 2020, 98, 228-231. [CrossRef] [PubMed]

73. Larsen, C.P.; Bourne, T.D.; Wilson, J.D.; Saqqa, O.; Sharshir, M.A. Collapsing Glomerulopathy in a Patient With COVID-19. Kidney Int. Rep. 2020, 5, 935-939. [CrossRef]

74. Magoon, S.; Bichu, P.; Malhotra, V.; Alhashimi, F.; Hu, Y.; Khanna, S.; Berhanu, K. COVID-19-Related Glomerulopathy: A Report of 2 Cases of Collapsing Focal Segmental Glomerulosclerosis. Kidney Med. 2020, 2, 488-492. [CrossRef] [PubMed] 
75. Noble, R.; Tan, M.Y.; McCulloch, T.; Shantier, M.; Byrne, C.; Hall, M.; Jesky, M. Collapsing Glomerulopathy Affecting Native and Transplant Kidneys in Individuals with COVID-19. Nephron 2020, 144, 589-594. [CrossRef]

76. Wu, H.; Larsen, C.P.; Hernandez-Arroyo, C.F.; Mohamed, M.M.B.; Caza, T.; Sharshir, M.; Chughtai, A.; Xie, L.; Gimenez, J.M.; Sandow, T.A.; et al. AKI and Collapsing Glomerulopathy Associated with COVID-19 and APOL 1 High-Risk Genotype. J. Am. Soc. Nephrol. 2020, 31, 1688-1695. [CrossRef]

77. Kadosh, B.S.; Pavone, J.; Wu, M.; Reyentovich, A.; Gidea, C. Collapsing glomerulopathy associated with COVID-19 infection in a heart transplant recipient. J. Heart Lung Transplant. 2020, 39, 855-857. [CrossRef]

78. Couturier, A.; Ferlicot, S.; Chevalier, K.; Guillet, M.; Essig, M.; Jaureguiberry, S.; Collarino, R.; Dargelos, M.; Michaut, A.; Geri, G.; et al. Indirect effects of severe acute respiratory syndrome coronavirus 2 on the kidney in coronavirus disease patients. Clin. Kidney J. 2020, 13, 347-353. [CrossRef]

79. Nlandu, Y.M.; Makulo, J.R.; Pakasa, N.M.; Sumaili, E.K.; Nkondi, C.N.; Bukabau, J.B.; Beya, F.K.; Nseka, N.M.; Lepira, F.B. First Case of COVID-19-Associated Collapsing Glomerulopathy in Sub-Saharan Africa. Case Rep. Nephrol. 2020, $2020,8820713$. [CrossRef]

80. Gupta, R.K.; Bhargava, R.; Shaukat, A.A.; Albert, E.; Leggat, J. Spectrum of podocytopathies in new-onset nephrotic syndrome following COVID-19 disease: A report of 2 cases. BMC Nephrol. 2020, 21, 326. [CrossRef]

81. Nasr, S.H.; Alexander, M.P.; Cornell, L.D.; Herrera, L.H.; Fidler, M.E.; Said, S.M.; Zhang, P.; Larsen, C.P.; Sethi, S. Kidney Biopsy Findings in Patients With COVID-19, Kidney Injury, and Proteinuria. Am. J. Kidney Dis. 2021, 77, 465-468. [CrossRef]

82. Lazareth, H.; Pere, H.; Binois, Y.; Chabannes, M.; Schurder, J.; Bruneau, T.; Karras, A.; Thervet, E.; Rabant, M.; Veyer, D.; et al COVID-19-Related Collapsing Glomerulopathy in a Kidney Transplant Recipient. Am. J. Kidney Dis. 2020, 76, 590-594. [CrossRef]

83. Rossi, G.M.; Delsante, M.; Pilato, F.P.; Gnetti, L.; Gabrielli, L.; Rossini, G.; Re, M.C.; Cenacchi, G.; Affanni, P.; Colucci, M.E.; et al Kidney Biopsy Findings in a Critically Ill COVID-19 Patient With Dialysis-Dependent Acute Kidney Injury: A Case Against "SARS-CoV-2 Nephropathy". Kidney Int. Rep. 2020, 5, 1100-1105. [CrossRef]

84. Papadimitriou, J.C.; Drachenberg, C.B.; Kleiner, D.; Choudhri, N.; Haririan, A.; Cebotaru, V. Tubular Epithelial and Peritubular Capillary Endothelial Injury in COVID-19 AKI. Kidney Int. Rep. 2021, 6, 518-525. [CrossRef] [PubMed]

85. Huang, Y.; Li, X.J.; Li, Y.Q.; Dai, W.; Shao, T.; Liu, W.Y.; Han, M.; Xu, G.; Liu, L. Clinical and pathological findings of SARS-CoV-2 infection and concurrent IgA nephropathy: A case report. BMC Nephrol. 2020, 21, 504. [CrossRef] [PubMed]

86. Sandhu, S.; Chand, S.; Bhatnagar, A.; Dabas, R.; Bhat, S.; Kumar, H.; Dixit, P.K. Possible association between IgA vasculitis and COVID-19. Dermatol. Ther. 2021, 34, e14551. [CrossRef] [PubMed]

87. Suso, A.S.; Mon, C.; Onate Alonso, I.; Galindo Romo, K.; Juarez, R.C.; Ramirez, C.L.; Sanchez Sanchez, M.; Mercado Valdivia, V.; Ortiz Librero, M.; Oliet Pala, A.; et al. IgA Vasculitis With Nephritis (Henoch-Schonlein Purpura) in a COVID-19 Patient. Kidney Int. Rep. 2020, 5, 2074-2078. [CrossRef]

88. Moeinzadeh, F.; Dezfouli, M.; Naimi, A.; Shahidi, S.; Moradi, H. Newly Diagnosed Glomerulonephritis During COVID-19 Infection Undergoing Immunosuppression Therapy, a Case Report. Iran. J. Kidney Dis. 2020, 14, $239-242$.

89. Uppal, N.N.; Kello, N.; Shah, H.H.; Khanin, Y.; De Oleo, I.R.; Epstein, E.; Sharma, P.; Larsen, C.P.; Bijol, V.; Jhaveri, K.D. De Novo ANCA-Associated Vasculitis With Glomerulonephritis in COVID-19. Kidney Int. Rep. 2020, 5, 2079-2083. [CrossRef]

90. Brix, S.R.; Jones, R.B.; Jayne, D.R.W. Glomerular basement membrane nephritis: Crescentic renal inflammation and immunosuppressive intervention in the time of the severe acute respiratory syndrome coronavirus 2 pandemic. Kidney Int. 2021, 99, 1234-1235. [CrossRef]

91. Koc, N.S.; Yildirim, T.; Saglam, A.; Arici, M.; Erdem, Y. A patient with COVID-19 and anti-glomerular basement membrane disease. Nefrologia 2021, 41, 471-473. [CrossRef]

92. Fontana, F.; Cazzato, S.; Giovanella, S.; Ballestri, M.; Leonelli, M.; Mori, G.; Alfano, G.; Ligabue, G.; Magistroni, R.; Cenacchi, G.; et al. Oxalate Nephropathy Caused by Excessive Vitamin C Administration in 2 Patients With COVID-19. Kidney Int. Rep. 2020, 5 , 1815-1822. [CrossRef] [PubMed]

93. Szajek, K.; Kajdi, M.E.; Luyckx, V.A.; Fehr, T.H.; Gaspert, A.; Cusini, A.; Hohloch, K.; Grosse, P. Granulomatous interstitial nephritis in a patient with SARS-CoV-2 infection. BMC Nephrol. 2021, 22, 19. [CrossRef]

94. Sethi, S.; D'Costa, M.R.; Hermann, S.M.; Nasr, S.H.; Fervenza, F.C. Immune-Complex Glomerulonephritis After COVID-19 Infection. Kidney Int Rep. 2021, 6, 1170-1173. [CrossRef]

95. Goldsmith, C.S.; Miller, S.E.; Martines, R.B.; Bullock, H.A.; Zaki, S.R. Electron microscopy of SARS-CoV-2: A challenging task Lancet 2020, 395, e99. [CrossRef]

96. Roufosse, C.; Curtis, E.; Moran, L.; Hollinshead, M.; Cook, T.; Hanley, B.; Horsfield, C.; Neil, D. Electron microscopic investigations in COVID-19: Not all crowns are coronas. Kidney Int. 2020, 98, 505-506. [CrossRef] [PubMed]

97. Oshiro, L.S.; Schieble, J.H.; Lennette, E.H. Electron microscopic studies of coronavirus. J. Gen. Virol. 1971, 12, 161-168. [CrossRef]

98. Gambella, A.; Barreca, A.; Osella-Abate, S.; Bottasso, E.; Giarin, M.M.; Papotti, M.; Biancone, L.; Metovic, J.; Collemi, G.; Cassoni, P.; et al. Caveolin-1 in Kidney Chronic Antibody-Mediated Rejection: An Integrated Immunohistochemical and Transcriptomic Analysis Based on the Banff Human Organ Transplant (B-HOT) Gene Panel. Biomedicines 2021, 9, 1318. [CrossRef]

99. Tervaert, T.W.; Mooyaart, A.L.; Amann, K.; Cohen, A.H.; Cook, H.T.; Drachenberg, C.B.; Ferrario, F.; Fogo, A.B.; Haas, M.; de Heer, E.; et al. Pathologic classification of diabetic nephropathy. J. Am. Soc. Nephrol. 2010, 21, 556-563. [CrossRef]

100. Su, H.; Yang, M.; Wan, C.; Yi, L.X.; Tang, F.; Zhu, H.Y.; Yi, F.; Yang, H.C.; Fogo, A.B.; Nie, X.; et al. Renal histopathological analysis of 26 postmortem findings of patients with COVID-19 in China. Kidney Int. 2020, 98, 219-227. [CrossRef] 
101. Punj, S.; Eng, E.; Shetty, A.A. Coronavirus disease 2019 and kidney injury. Curr. Opin. Nephrol. Hypertens 2021, 30, 444-449. [CrossRef] [PubMed]

102. Miller, S.E.; Brealey, J.K. Visualization of putative coronavirus in kidney. Kidney Int. 2020, 98, 231-232. [CrossRef]

103. Calomeni, E.; Satoskar, A.; Ayoub, I.; Brodsky, S.; Rovin, B.H.; Nadasdy, T. Multivesicular bodies mimicking SARS-CoV-2 in patients without COVID-19. Kidney Int. 2020, 98, 233-234. [CrossRef] [PubMed]

104. Farouk, S.S.; Fiaccadori, E.; Cravedi, P.; Campbell, K.N. COVID-19 and the kidney: What we think we know so far and what we don't. J. Nephrol. 2020, 33, 1213-1218. [CrossRef] [PubMed]

105. Hassler, L.; Reyes, F.; Sparks, M.A.; Welling, P.; Batlle, D. Evidence For and Against Direct Kidney Infection by SARS-CoV-2 in Patients with COVID-19. Clin. J. Am. Soc. Nephrol. 2021, 16, 1755-1765. [CrossRef]

106. Shah, S.A.; Carter, H.P. New-Onset Nephrotic Syndrome in a Child Associated With COVID-19 Infection. Front. Pediatr. 2020, 8, 471. [CrossRef]

107. Alvarado, A.; Franceschi, G.; Resplandor, E.; Sumba, J.; Orta, N. COVID-19 associated with onset nephrotic syndrome in a pediatric patient: Coincidence or related conditions? Pediatr. Nephrol. 2021, 36, 205-207. [CrossRef]

108. Bjornstad, E.C.; Seifert, M.E.; Sanderson, K.; Feig, D.I. Kidney implications of SARS-CoV2 infection in children. Pediatr. Nephrol. 2021. [CrossRef] [PubMed]

109. Morello, W.; Vianello, F.A.; Proverbio, E.; Peruzzi, L.; Pasini, A.; Montini, G. COVID-19 and idiopathic nephrotic syndrome in children: Systematic review of the literature and recommendations from a highly affected area. Pediatr. Nephrol. 2021. [CrossRef]

110. Stewart, D.J.; Hartley, J.C.; Johnson, M.; Marks, S.D.; du Pre, P.; Stojanovic, J. Renal dysfunction in hospitalised children with COVID-19. Lancet Child. Adolesc. Health 2020, 4, e28-e29. [CrossRef]

111. Serafinelli, J.; Mastrangelo, A.; Morello, W.; Cerioni, V.F.; Salim, A.; Nebuloni, M.; Montini, G. Kidney involvement and histological findings in two pediatric COVID-19 patients. Pediatr. Nephrol. 2021, 36, 3789-3793. [CrossRef]

112. Basiratnia, M.; Derakhshan, D.; Yeganeh, B.S.; Derakhshan, A. Acute necrotizing glomerulonephritis associated with COVID-19 infection: Report of two pediatric cases. Pediatr. Nephrol. 2021, 36, 1019-1023. [CrossRef]

113. Zamora, G.; Pearson-Shaver, A.L. Minimal Change Disease. In StatPearls; StatPearls Publishing: Treasure Island, FL, USA, 2022.

114. Yamada, M.; Rastogi, P.; Ince, D.; Thayyil, A.; Adela Mansilla, M.; Smith, R.J.H.; Kuppachi, S.; Thomas, C.P. Minimal Change Disease With Nephrotic Syndrome Associated With Coronavirus Disease 2019 After Apolipoprotein L1 Risk Variant Kidney Transplant: A Case Report. Transplant. Proc. 2020, 52, 2693-2697. [CrossRef] [PubMed]

115. Shimada, M.; Araya, C.; Rivard, C.; Ishimoto, T.; Johnson, R.J.; Garin, E.H. Minimal change disease: A "two-hit" podocyte immune disorder? Pediatr. Nephrol. 2011, 26, 645-649. [CrossRef]

116. Ishimoto, T.; Shimada, M.; Araya, C.E.; Huskey, J.; Garin, E.H.; Johnson, R.J. Minimal change disease: A CD80 podocytopathy? Semin. Nephrol. 2011, 31, 320-325. [CrossRef] [PubMed]

117. Kim, S.R.; Lee, S.B.; Kim, I.Y.; Lee, D.W.; Rhee, H.; Seong, E.Y.; Song, S.H.; Kwak, I.S. Relapse of minimal change disease following infection with the 2009 pandemic influenza (H1N1) virus. Clin. Exp. Nephrol. 2012, 16, 329-332. [CrossRef]

118. Bomback, A.S.; Appel, G.B. Pathogenesis of the C3 glomerulopathies and reclassification of MPGN. Nat. Rev. Nephrol. 2012, 8, 634-642. [CrossRef] [PubMed]

119. Lebreton, C.; Bacchetta, J.; Dijoud, F.; Bessenay, L.; Fremeaux-Bacchi, V.; Sellier-Leclerc, A.L. C3 glomerulopathy and eculizumab: A report on four paediatric cases. Pediatr. Nephrol. 2017, 32, 1023-1028. [CrossRef]

120. Servais, A.; Noel, L.H.; Roumenina, L.T.; Le Quintrec, M.; Ngo, S.; Dragon-Durey, M.A.; Macher, M.A.; Zuber, J.; Karras, A.; Provot, F.; et al. Acquired and genetic complement abnormalities play a critical role in dense deposit disease and other C3 glomerulopathies. Kidney Int. 2012, 82, 454-464. [CrossRef]

121. Castagnoli, R.; Votto, M.; Licari, A.; Brambilla, I.; Bruno, R.; Perlini, S.; Rovida, F.; Baldanti, F.; Marseglia, G.L. Severe Acute Respiratory Syndrome Coronavirus 2 (SARS-CoV-2) Infection in Children and Adolescents: A Systematic Review. JAMA Pediatr. 2020, 174, 882-889. [CrossRef]

122. de Souza, T.H.; Nadal, J.A.; Nogueira, R.J.N.; Pereira, R.M.; Brandao, M.B. Clinical manifestations of children with COVID-19: A systematic review. Pediatr. Pulmonol. 2020, 55, 1892-1899. [CrossRef]

123. Panahi, L.; Amiri, M.; Pouy, S. Clinical Characteristics of COVID-19 Infection in Newborns and Pediatrics: A Systematic Review. Arch. Acad. Emerg. Med. 2020, 8, e50. [PubMed]

124. Mustafa, N.M.; Selim, L.A. Characterisation of COVID-19 Pandemic in Paediatric Age Group: A Systematic Review and Meta-Analysis. J. Clin. Virol. 2020, 128, 104395. [CrossRef]

125. Hoang, A.; Chorath, K.; Moreira, A.; Evans, M.; Burmeister-Morton, F.; Burmeister, F.; Naqvi, R.; Petershack, M.; Moreira, A. COVID-19 in 7780 pediatric patients: A systematic review. EClinicalMedicine 2020, 24, 100433. [CrossRef] [PubMed]

126. Mastrangelo, A.; Morello, W.; Vidal, E.; Guzzo, I.; Annicchiarico Petruzzelli, L.; Benetti, E.; Materassi, M.; Giordano, M.; Pasini, A.; Corrado, C.; et al. Impact of COVID-19 Pandemic in Children with CKD or Immunosuppression. Clin. J. Am. Soc. Nephrol. 2021, 16, 449-451. [CrossRef]

127. Nicastro, E.; Verdoni, L.; Bettini, L.R.; Zuin, G.; Balduzzi, A.; Montini, G.; Biondi, A.; D'Antiga, L. COVID-19 in Immunosuppressed Children. Front. Pediatr. 2021, 9, 629240. [CrossRef]

128. Liakopoulos, V.; Roumeliotis, S.; Papachristou, S.; Papanas, N. COVID-19 and the kidney: Time to take a closer look. Int. Urol. Nephrol. 2021. [CrossRef] 
129. Bibbo, C. Reconstruction of COVID-19-Related Compartment Syndrome With Massive Soft Tissue Necrosis. Wounds 2021, 33, 99-105. [PubMed]

130. Maritati, F.; Moretti, M.I.; Nastasi, V.; Mazzucchelli, R.; Morroni, M.; Bagnarelli, P.; Rupoli, S.; Tavio, M.; Galiotta, P.; Bisello, W.; et al. ANCA-Associated Glomerulonephritis and Anti-Phospholipid Syndrome in a Patient with SARS-CoV-2 Infection: Just a Coincidence? Case Rep. Nephrol. Dial. 2021, 11, 214-220. [CrossRef]

131. Miao, J.; Fidler, M.E.; Nasr, S.H.; Larsen, C.P.; Zoghby, Z.M. Membranous nephropathy in a patient with coronavirus disease 2019 (COVID-19): A case report. Clin. Nephrol. Case Stud. 2021, 9, 11-18. [CrossRef]

132. Tarragon, B.; Valdenebro, M.; Serrano, M.L.; Maroto, A.; Llopez-Carratala, M.R.; Ramos, A.; Rubio, E.; Huerta, A.; Marques, M.; Portoles, J. Acute kidney failure in patients admitted due to COVID-19. Nefrologia 2021, 41, 34-40. [CrossRef] [PubMed]

133. Chueh, T.I.; Zheng, C.M.; Hou, Y.C.; Lu, K.C. Novel Evidence of Acute Kidney Injury in COVID-19. J. Clin. Med. 2020, 9, 3547. [CrossRef] [PubMed]

134. Taghizadieh, A.; Mikaeili, H.; Ahmadi, M.; Valizadeh, H. Acute kidney injury in pregnant women following SARS-CoV-2 infection: A case report from Iran. Respir Med. Case Rep. 2020, 30, 101090. [CrossRef] [PubMed]

135. Li, J.; Li, S.X.; Zhao, L.F.; Kong, D.L.; Guo, Z.Y. Management recommendations for patients with chronic kidney disease during the novel coronavirus disease 2019 (COVID-19) epidemic. Chronic. Dis. Transl. Med. 2020, 6, 119-123. [CrossRef] [PubMed]

136. Basic-Jukic, N.; Coric, M.; Bulimbasic, S.; Dika, Z.; Juric, I.; Furic-Cunko, V.; Katalinic, L.; Kos, J.; Fistrek, M.; Kastelan, Z.; et al Histopathologic findings on indication renal allograft biopsies after recovery from acute COVID-19. Clin. Transplant. 2021, 35, e14486. [CrossRef] [PubMed]

137. Akalin, E.; Azzi, Y.; Bartash, R.; Seethamraju, H.; Parides, M.; Hemmige, V.; Ross, M.; Forest, S.; Goldstein, Y.D.; Ajaimy, M.; et al. Covid-19 and Kidney Transplantation. N. Engl. J. Med. 2020, 382, 2475-2477. [CrossRef] [PubMed]

138. Daniel, E.; Sekulic, M.; Kudose, S.; Kubin, C.; Ye, X.; Shayan, K.; Patel, A.; Cohen, D.J.; ERatner, L.; Santoriello, D.; et al. Kidney allograft biopsy findings after COVID-19. Am. J. Transplant. 2021, 21, 4032-4042. [CrossRef] [PubMed]

139. Rosenberg, A.Z.; Naicker, S.; Winkler, C.A.; Kopp, J.B. HIV-associated nephropathies: Epidemiology, pathology, mechanisms and treatment. Nat. Rev. Nephrol. 2015, 11, 150-160. [CrossRef]

140. Velez, J.C.Q.; Caza, T.; Larsen, C.P. COVAN is the new HIVAN: The re-emergence of collapsing glomerulopathy with COVID-19. Nat. Rev. Nephrol. 2020, 16, 565-567. [CrossRef] 